\title{
First molecular phylogeny of the subfamily Polycerinae (Mollusca, Nudibranchia, Polyceridae)
}

\author{
Gemma Palomar · Marta Pola • Eva Garcia-Vazquez
}

Received: 16 July 2013/Revised: 17 October 2013/Accepted: 27 October 2013/Published online: 9 November 2013

(C) Springer-Verlag Berlin Heidelberg and AWI 2013

\begin{abstract}
The subfamily Polycerinae includes four genera with around 46 species described to date. This subfamily is characterized by a limaciform body, which may have simple tentacular processes on the margin of the oral veil. Phylogenetic relationships between the genera of the subfamily Polycerinae (Polyceridae) have not yet been studied, and therefore, the only available information is based on morphological descriptions. The present study reports the first phylogenetic analysis of Polycerinae based on the mitochondrial genes cytochrome oxidase subunit I and the large ribosomal subunit (16S rRNA) using maximum likelihood and Bayesian methods. Our results showed that Polycerinae is monophyletic, but the relationships within the subfamily as well as within Polycera remain unresolved. A key finding of this study is that there are clearly two sympatric species of Polycera present in South Africa: Polycera capensis Quoy and Gaimard, 1824 also found in Australia and an undescribed Polycera sp. On the other hand, the studied specimens of the genus Gymnodoris were clustered within Polycerinae, reopening the problem of the systematic position of this genus. Additional genes
\end{abstract}

Communicated by H.-D. Franke.

G. Palomar $(\bowtie) \cdot$ E. Garcia-Vazquez

Departamento de Biología Funcional, Universidad de Oviedo,

C/ Julian Claveria s/n, 33006 Oviedo, Spain

e-mail: gemma.palomar@yahoo.es

E. Garcia-Vazquez

e-mail: egv@uniovi.es

M. Pola

Departamento de Biología, Universidad Autónoma de Madrid, Edificio de Biología, Campus de Excelencia Internacional

UAM+CSIC, C/ Darwin, 2, 28049 Madrid, Spain

e-mail: marta.pola@uam.es and species of Polycerinae and Gymnodoris would provide more information and probably fully resolve this situation.

Keywords COI $\cdot 16 \mathrm{~S} \cdot$ Gymnodoris $\cdot$ Nudibranchia . Polycerinae $\cdot$ Polycera capensis

\section{Introduction}

The absence of nudibranchs in fossil records has complicated the understanding of their biology and evolution (Valdés 2001). Despite this limitation, many studies based on classical morphology have been undertaken since the nineteenth century (e.g., Alder and Hancock 1845-1855; Bergh 1877, 1890, 1902, 1906; Odhner 1934; Valdés and Gosliner 1999; Wägele and Willan 2000; Valdés 2001, 2002; Fahey and Gosliner 2001, 2004; Gosliner 2004; Pola et al. 2005a, 2006a). However, a taxonomy based only on morphology has its limits (Medina and Walsh 2000; Wiens and Penkrot 2002; Fall et al. 2003; Dayrat 2005). Morphological characters may vary within the same species as the result of selective pressures and adaptation to varying environmental parameters (Wägele 2005), and the choice of taxonomically informative characteristics depends on the criteria of taxonomists (Mikkelsen 1998). Molecular techniques can palliate these limitations (Medina and Collins 2003; Wägele et al. 2003; Wägele 2005; OrnelasGatdula et al. 2012; Pola et al. 2012; Carmona et al. 2013). Mitochondrial genes have provided interesting information on the phylogeny of nudibranchs (Thöllesson 1999a, b, 2000; Medina et al. 2001; Wollscheid-Lengeling et al. 2001; Fahey 2003; Valdés 2003; Wilson and Lee 2005; Pola et al. 2007; Turner and Wilson 2008; Johnson 2010; Pola and Gosliner 2010; Johnson and Gosliner 2012; Carmona et al. 2013). The results of these researches have 
clarified the relationships within some groups, but there are still many unclear phylogenetic relationships, for example, within species grouped under the family Polyceridae Alder and Hancock, 1845 (superfamily Polyceroidea, subclade Doridacea, clade Euctenidiacea; Bouchet and Rocroi 2005). This family includes a group of nudibranchs that have elongate and limaciform bodies and a reduced mantle skirt. Their lamellate rhinophores have a pocket, and sometimes a sheath into which they can retract, although their gills are non-retractile. In the past, it was related to notodorids and gymnodorids. Old classifications included gymnodorids as subfamily Gymnodoridinae within the family Polyceridae (Eliot, 1903), although other authors such as Odhner (1941) believed they should be regarded as distinct. Macnae (1958) considered that gymnodorids and polycerids shared enough characters to belong to the same family. Both have their principal ganglia concentrated into a compact mass above and alongside the esophagus. Their pleural and cerebral ganglia are usually enclosed in the same sheath and are not easily distinguishable when viewed from above. Their abdominal ganglion is drawn up so as to lie close to the pleural ganglion on the right side. They have a blood gland in association with the anterior aorta, lying in the mass of connective tissue overlying the posterior portion of the anterior genital mass. Only the buccal region and its armature, the form of the radula and its teeth, are different in both families and are used as diagnostic characters even at species level (Macnae 1958). Nowadays, Gymnodorididae is considered a separated family (Bouchet and Rocroi 2005; Bouchet 2013) although, to date, the relationship between gymnodorids and polycerids remains unresolved.

At present, Polyceridae comprises four subfamilies: Polycerinae, Triophinae, Nembrothinae and Kalinginae (Burn 1967; Rudman 1998). Ortea et al. (2004) proposed a new subfamily, Kankelibranchinae, based on a unique specimen from Cuba. In the subfamily Triophinae, the genera Kaloplocamus and Plocamopherus have been revised (Vallés and Gosliner 2006). However, information about the genera Crimora, Limacia and Triopha, among others, is still very limited. Nembrothinae, with its genera Tambja, Nembrotha and Roboastra, have been quite intensely studied (Pola et al. 2003, 2005a, b, c, 2006a, b, c, 2007, 2008a, b). The remaining subfamilies still remain genetically unexplored.

The subfamily Polycerinae is characterized by a limaciform body, which may have simple tentacular processes on the margin of the oral veil. On the sides of the body, the mantle is reduced to a few tentacular papillae, which are sometimes connected by a ridge. Rhinophores are lamellate, while and gills are often simple pinnate. They lack buccal pump and have large chitinous jaws usually with a wing-like accessory process. The two innermost lateral teeth on each side are usually large, bicuspidate and hooked, while the outer teeth are much smaller and acuspidate plates. The penis is usually armed with spines (Rudman 1998; Wägele and Willan 2000). There are four genera included within Polycerinae: Polycera Cuvier, 1817 (31 species), Polycerella Verril, 1880 (2 species), Palio Gray, 1857 (6 species) and Thecacera Fleming, 1828 (7 species), with around 46 species described plus two considered as nomina dubia, Polycera funerea Pruvot-Fol, 1930 and Polycera pruvotae Risbec, 1953 (Boxshall et al. 2013). Phylogenetic relationships within Polycerinae and between Polyceridae subfamilies are unknown. There are only some monographs referring to some Polycerinae species (Müller 1776; Quoy and Gaimard 1824; MacFarland 1905; Lemche 1929; Marcus 1964; Robilliard 1971; García and Bobo 1984), and few taxa have been included in phylogenetic studies focused on other families or with other aims (Wollscheid and Wägele 1999; Thöllesson 1999b, 2000; Pola et al. 2007; Pola and Gosliner 2010).

Within Polycera, the taxonomic status of Polycera capensis Quoy and Gaimard, 1824 is repeatedly a matter of debate. It was originally described from South Africa and lately commonly reported from Sydney to Port Stephens in New South Wales and eastern Australia (Rudman 1998). It is thought that $P$. capensis was introduced from South Africa to Australia by fouling, and it has spread $200 \mathrm{~km}$ since then (Macnae 1958; Willan 2000) although some authors have considered the Australian Polycera capensis to be a different species (Allan 1932; Thompson 1975). Taking into account the variability shown in this subfamily by other species, for example Polycera quadrilineata (Alder 1841; Alder and Hancock 1845; Odhner 1941), a more complete phylogenetic study of Polycera capensis is needed to shed light on this controversial matter.

The objectives of this study are to: (1) test the monophyly of Polycerinae giving the first molecular insight of the phylogenetic relationships within this subfamily, with emphasis on the genus Polycera; (2) discuss the relationship between polycerids and gymnodorids; and (3) evaluate the conspecificity of specimens of Polycera capensis from South Africa and Australia.

\section{Materials and methods}

Samples analyzed

Samples were obtained from specimens deposited at the Museo Nacional de Ciencias Naturales, Madrid (MNCN), the California Academy of Sciences, San Francisco (CASIZ), and the Museu Municipal de Funchal, Madeira (MMF). DNA was successfully extracted from 50 samples, corresponding to 37 specimens and 13 species of the 
Table 1 Specimens used for molecular analysis, locality, voucher and GenBank accession number

\begin{tabular}{|c|c|c|c|c|}
\hline \multirow[t]{2}{*}{ Species } & \multirow[t]{2}{*}{ Locality } & \multirow[t]{2}{*}{ Voucher } & \multicolumn{2}{|c|}{ GenBank Accesion Number } \\
\hline & & & $\mathrm{COI}$ & $16 \mathrm{~S}$ \\
\hline Polycera quadrilineata & United Kingdom, Oban & MNCN15.05/46738 & EF142907 & EF142953 \\
\hline Polycera quadrilineata & Kattegat, North Sea & GB1 & - & AF249229 \\
\hline Polycera quadrilineata & Sweden, Bohuslän, Kristineberg & GB2 & $\mathrm{AJ} 223275$ & AJ225200 \\
\hline Polycera quadrilineata & Sweden, Gothenborg, Tjärnö & MNCN15.05/55458 & - & JX274040 \\
\hline Polycera quadrilineata & Sweden, Gothenborg, Tjärnö & MNCN15.05/55462 & JX274070 & JX274041 \\
\hline Polycera quadrilineata & Sweden, Gothenborg, Tjärnö & MNCN15.05/55465 & JX274071 & JX274042 \\
\hline Polycera quadrilineata & Sweden, Gothenborg, Tjärnö & MNCN15.05/55456 & JX274072 & JX274043 \\
\hline Polycera quadrilineata & Sweden, Gothenborg, Tjärnö & MNCN15.05/55466 & JX274073 & JX274044 \\
\hline Polycera quadrilineata & Sweden, Gothenborg, Tjärnö & MNCN15.05/55463 & JX274074 & JX274045 \\
\hline Polycera quadrilineata & Sweden, Gothenborg, Tjärnö & MNCN15.05/55464 & JX274075 & - \\
\hline Polycera quadrilineata & Sweden, Gothenborg, Tjärnö & MNCN15.05/55457 & JX274076 & - \\
\hline Polycera quadrilineata & Sweden, Gothenborg, Tjärnö & MNCN15.05/55459 & JX274077 & JX274046 \\
\hline Polycera quadrilineata & Sweden, Gothenborg, Tjärnö & MNCN15.05/55460 & JX274078 & - \\
\hline Polycera quadrilineata & Sweden, Gothenborg, Tjärnö & MNCN15.05/55455 & JX274079 & JX274047 \\
\hline Polycera faeroensis & Portugal, Estacada, Aveiro & MNCN15.05/55503.1 & JX274088 & - \\
\hline Polycera faeroensis & Portugal, Estacada, Aveiro & MNCN15.05/55503.2 & JX274089 & JX274056 \\
\hline Polycera aurantiomarginata & Spain, Cádiz & GB & $\mathrm{AJ} 223274$ & AJ225199 \\
\hline Polycera aurantiomarginata & Morocco, Aghroud & MNCN15.05/55483 & - & JX274037 \\
\hline Polycera aurantiomarginata & Morocco, Aghroud & MNCN15.05/55492 & JX274068 & JX274038 \\
\hline Polycera aurantiomarginata & Morocco, Aghroud & MNCN15.05/55490 & JX274069 & JX274039 \\
\hline Polycera hedgpethi & Morocco, Aghroud & MNCN15.05/55493 & JX274086 & - \\
\hline Polycera atra & $\begin{array}{l}\text { California, San Francisco Bay, San Francisco } \\
\text { Marina }\end{array}$ & CASIZ170506a & JX274084 & JX274052 \\
\hline Polycera atra & $\begin{array}{l}\text { California, San Francisco Bay, San Francisco } \\
\text { Marina }\end{array}$ & CASIZ170506b & JX274085 & JX274053 \\
\hline Polycera capensis & South Africa, Western Cape province, Hout Bay & CASIZ176907 & HM162687 & HM162597 \\
\hline Polycera capensis & $\begin{array}{l}\text { South Africa, Cape province, Atlantic coast, } \\
\text { Oudekraal }\end{array}$ & CASIZ176280 & JX274091 & - \\
\hline Polycera capensis & South Africa, Western Cape Province, False Bay & CASIZ176375 & JX274092 & JX274058 \\
\hline Polycera cf. capensis & Australia, New South Wales, Nelson Bay & MNCN15.05/55470 & JX274083 & JX274051 \\
\hline Polycera tricolor & $\begin{array}{l}\text { California, San Francisco Estuary, San Francisco } \\
\text { Bay, Marin County }\end{array}$ & CASIZ76438a & JX274087 & JX274054 \\
\hline Polycera tricolor & $\begin{array}{l}\text { California, San Francisco Estuary, San Francisco } \\
\text { Bay, Marin County }\end{array}$ & CASIZ76438b & - & JX274055 \\
\hline Polycera sp. A & $\begin{array}{l}\text { South Africa, Western Cape Province, False Bay, } \\
\text { Gordon's Bay }\end{array}$ & CASIZ176169 & JX274081 & JX274049 \\
\hline Polycera sp. A & $\begin{array}{l}\text { South Africa, Eastern Cape Province, Tsitsikamma } \\
\text { Coastal National Park }\end{array}$ & CASIZ176387 & JX274082 & JX274050 \\
\hline Polycera sp. B & Hawaii, Maui, Maalaea Bay & CASIZ176795 & JX274093 & - \\
\hline Polycera sp. C & $\begin{array}{l}\text { Pacific Ocean, Marshall Islands, Kwajalein Atoll, } \\
\text { Onemak Pinnacle }\end{array}$ & CASIZ120773 & JX274090 & JX274057 \\
\hline Polycerella emertoni & Spain, Cádiz & GB & AJ223273 & AJ225198 \\
\hline Polycerella emertoni & Spain, Cádiz, Santi Petri & MNCN15.05/55480 & JX274095 & JX274060 \\
\hline Polycerella emertoni & Spain, Cádiz, Santi Petri, dock & MNCN15.05/55479.1 & JX274096 & - \\
\hline Polycerella emertoni & Spain, Cádiz, Santi Petri, dock & MNCN15.05/55479.2 & JX274097 & - \\
\hline Polycerella emertoni & Spain, Cádiz, Santi Petri, dock & MNCN15.05/55482 ${ }^{\mathrm{a}}$ & JX274098 & JX274061 \\
\hline Polycerella emertoni & Spain, Cádiz, Santi Petri, dock & MNCN15.05/55482 ${ }^{\mathrm{a}}$ & JX274099 & JX274062 \\
\hline Thecacera pennigera & Spain, Cádiz & GB & AJ223277 & AJ225202 \\
\hline
\end{tabular}


Table 1 continued

\begin{tabular}{|c|c|c|c|c|}
\hline \multirow[t]{2}{*}{ Species } & \multirow[t]{2}{*}{ Locality } & \multirow[t]{2}{*}{ Voucher } & \multicolumn{2}{|c|}{ GenBank Accesion Number } \\
\hline & & & $\mathrm{COI}$ & $16 \mathrm{~S}$ \\
\hline Thecacera pennigera & $\begin{array}{l}\text { South Africa, Cape province, Atlantic coast, } \\
\text { Oudekraal }\end{array}$ & CASIZ176285 & JX274094 & JX274059 \\
\hline Palio dubia & Sweden, Bohuslän, Kristineberg & GB & AJ 223272 & AJ225197 \\
\hline Palio dubia & Sweden, Gullmaren & MNCN15.05/55467 & JX274100 & - \\
\hline Gymnodoris alba & Australia, New South Wales, Nelson Bay & MNCN15.05/55472 & JX274101 & JX274063 \\
\hline Gymnodoris striata & Australia, Queensland & GB & HQ987955.1 & - \\
\hline Plocamopherus maderae & Cape Verde Archipelago, Sal Island & MNCN15.05/46735 & EF142905 & EF142951 \\
\hline Plocamopherus tilesii & Australia, New South Wales, Nelson Bay & MNCN15.05/55475 & JX274102 & JX274064 \\
\hline Plocamopherus imperialis & Australia, New South Wales, Nelson Bay & MNCN15.05/55468 & JX274103 & JX274065 \\
\hline Kaloplocamus ramosus & Portugal, Azores & GB & EF142904 & - \\
\hline Kaloplocamus ramosus & Australia, New South Wales, Nelson Bay & MNCN15.05/55473 & JX274104 & JX274066 \\
\hline Kaloplocamus ramosus & Australia, New South Wales, Nelson Bay & MNCN15.05/55471 & JX274105 & - \\
\hline Crimora lutea & Australia, Western Australia: Abrolhos Is. & MNCN15.05/46737 & EF142903 & EF142950 \\
\hline Crimora papillata & Spain, Mediterranean Sea & GB & AF249821 & - \\
\hline Triopha maculata & California, Marin County, Duxbury Reef & CASIZ181556 & HM162691 & HM162601 \\
\hline Triopha catalinae & $\begin{array}{l}\text { California, San Francisco, San Francisco Yacht } \\
\text { Harbor }\end{array}$ & CASIZ170648 & HM162690 & HM162600 \\
\hline Limacia clavigera & Spain, Cádiz, Bajo Cabezuela & MNCN 15.05/46736 & EF142906 & EF142952 \\
\hline Nembrotha mullineri & Philippines, Malapascua Is., Lapus-Lapus & MNCN 15.05/46723 & EF142895 & EF142944 \\
\hline Nembrotha guttata & Philippines, Siguijor Island, Siguijor Wall & WAMS11556 & EF142894 & EF142943 \\
\hline Roboastra luteolineata & Japan, Okinawa, Kerama Is., Zamami Is & MNCN15.05/46731 & EF142861 & EF142910 \\
\hline Roboastra caboverdensis & Cape Verde, Santo Antão Is & MNCN 15.05/46614 & EF142859 & EF142908 \\
\hline Tambja simplex & Cape Verde, Isla de San Vicente & MNCN 15.05/46680 & EF142874 & EF142925 \\
\hline Tambja fantasmalis & Cape Verde, Boavista Is., Baía das Gatas & MNCN 15.05/46734 & EF142873 & EF142924 \\
\hline Trapania hispalensis & Portugal, Aveiro & MNCN15.05/55504 & JX274080 & JX274048 \\
\hline Okenia rosacea & $\begin{array}{l}\text { United States, California, Marin County, Duxbuty } \\
\text { Reef }\end{array}$ & CASIZ 184340 & KF192605 & - \\
\hline Okenia aтоепula & South Africa, False Bay & CASIZ 176191 & KF192606 & - \\
\hline Ancula gibbosa & Sweden, Bohuslän, Kristineberg & GB & AJ 223255 & AJ225179 \\
\hline Montereina concinna & Australia, Great Barrier & GB & AF249801 & AF249228 \\
\hline Jorunna tomentosa & Sweden, Bohuslän, Kristineberg & GB & AJ223267 & AJ225191 \\
\hline Platydoris argo & Ceuta, Strait of Gibraltar & GB & AY345037 & AY345037 \\
\hline Felimida krohni & Murcia, SE Spain & GB & AY345036 & AY345036 \\
\hline Felimare picta & Spain, Atlantic & GB & AF249787 & AF249238 \\
\hline Phyllidia elegans & Tab Island, Papua New Guinea & GB & AJ223276 & AJ225201 \\
\hline Doriopsilla areolata & Cádiz, Andalucia, Spain & GB & AJ223262 & AJ225186 \\
\hline Bathydoris clavigera & Antarctica, South Shetland Islands, Elephant Island & CASIZ167553 & JX274106 & JX274067 \\
\hline
\end{tabular}

GB, sequences obtained from Genbank

${ }^{a}$ The whole specimen was used for the extraction, this voucher belongs to a tube with another 10 specimens recollected the same date and place

subfamily Polycerinae (10 Polycera, 1 Polycerella, 1 Thecacera, 1 Palio). PCR amplification of cytochrome oxidase subunit I (COI) and 16S rRNA genes was obtained for 38 and 30 samples, respectively. Sequences were submitted to GenBank, and the accession numbers are given in Table 1 as well as locality of origin and the voucher reference. DNA extraction and PCR amplification were carried out at the University of Oviedo (Spain).
In addition, in order to test the monophyly of Polycerinae, available sequences from the GenBank were used for species belonging to Polycerinae, Nembrothinae and Triophinae, plus species belonging to six families within Doridacea (Bouchet and Rocroi 2005): Discodorididae (Montereina concinna, Jorunna tomentosa, and Platydoris argo), Chromodorididae (Felimida krohni, and Felimare picta), Goniodorididae (Ancula gibbosa), Gymnodorididae 
(Gymnodoris striata), Phyllidiidae (Phyllidia elegans) and Dendrodorididae (Doriopsilla areolata) (Table 1). As in other phylogenetic studies involving this family, Bathydoris clavigera was chosen as the outgroup (Millen and Martinov 2005; Pola et al. 2005a, 2006b, 2007), based on its condition of sister taxon (Wägele 1989; Wägele and Willan 2000; Schrödl et al. 2001; Wollscheid-Lengeling et al. 2001; Valdés 2002).

DNA extraction, PCR amplification and sequencing

Genomic DNA was extracted from the preserved tissue samples either from the foot or the mantle using the Chelex ${ }^{\circledR}$ resin (Bio-Rad Laboratories) according Estoup's et al. (1996) protocol. The tissue was introduced in an Eppendorf tube with $500 \mu \mathrm{l}$ of Chelex resin $(10 \%)$ and $7.5 \mu \mathrm{l}$ of Proteinase $\mathrm{K}(20 \mathrm{mg} / \mathrm{ml})$. It was incubated at $55^{\circ} \mathrm{C}$ for $90 \mathrm{~min}$ (vortex every $15 \mathrm{~min}$ ), and then introduced in an oven at $100{ }^{\circ} \mathrm{C}$ for $20 \mathrm{~min}$ to inactivate the enzyme. The tube was then stored at $4{ }^{\circ} \mathrm{C}$ or frozen at $-20{ }^{\circ} \mathrm{C}$ for longtime preservation.

Polymerase chain reaction (PCR) was employed to amplify fragments of the COI and 16S rRNA genes. We used the primers designed by Palumbi et al. (1991) for $16 \mathrm{~S}$ rRNA: 16Sar-L (5'-CGCCTGTTTATCAAAAACAT-3') and $16 \mathrm{Sbr}-\mathrm{H}$ (5'-CCGGTCTGAACTCAGATCACGT-3'), and by Folmer et al. (1994) for COI: LCO1490 (5'GGTCAACAAATCATAAAGATATTGG-3') and ${ }^{\prime}$ HCO2 198 (5'-TAAACTTCAGGG TGACCAAAAAATCA-3').

The amplification reaction was performed in a total volume of $40 \mu \mathrm{l}$, including $8 \mu \mathrm{l}$ of Promega (Madison, WI) buffer $1 \times, 4 \mu \mathrm{l}$ of $\mathrm{MgCl}_{2}$ (25 mM), $4 \mu \mathrm{ldNTPs}(2.5 \mathrm{mM})$, $2 \mu \mathrm{l}$ of each primer $(20 \mu \mathrm{M}), 4-10 \mu \mathrm{l}$ of template DNA and $1 \mathrm{U}$ of DNA Taq polymerase (Promega).

The PCR conditions for COI were the following: an initial denaturing step at $94{ }^{\circ} \mathrm{C}$ for $10 \mathrm{~min}$, then 40 cycles of denaturing at $94^{\circ} \mathrm{C}$ for $1 \mathrm{~min}$, annealing at $46^{\circ} \mathrm{C}$ for $1 \mathrm{~min}$ and extension at $72{ }^{\circ} \mathrm{C}$ for $1 \mathrm{~min}$, followed by a final extension at $72{ }^{\circ} \mathrm{C}$ for $8 \mathrm{~min}$. PCR conditions for the $16 \mathrm{~S}$ gene were similar, except it was run for 35 cycles and the annealing temperature was $48{ }^{\circ} \mathrm{C}$.

PCR products were visualized in $2 \%$ agarose gels with $3 \mu \mathrm{l}$ of $10 \mathrm{mg} / \mathrm{ml}$ ethidium bromide. Stained bands were excised from the gel, and DNA was purified with Wizard ${ }^{\circledR}$ SV Gel and PCR clean-up System (Promega) prior to sequencing. Then, DNA quantification and pre-sequencing PCR (initial denaturing step at $96{ }^{\circ} \mathrm{C}$ for 1 min followed by 25 cycles of denaturation at $96{ }^{\circ} \mathrm{C}$ for $10 \mathrm{~s}$, annealing at $50{ }^{\circ} \mathrm{C}$ for $5 \mathrm{~s}$ and extension at $60{ }^{\circ} \mathrm{C}$ for $4 \mathrm{~min}$, and final extension at $60{ }^{\circ} \mathrm{C}$ for $10 \mathrm{~min}$ ) were carried out. Products were precipitated using standard 2-propanol precipitation and re-suspended in formamide. Sequencing was performed with an ABI PRISM 3100 Genetic Analyzer
(Applied Biosystems) with BigDye 3.1 terminator system, at the Sequencing Unit of the University of Oviedo (Spain).

Sequence edition and phylogenetic analysis

Sequences were assembled and edited using BioEdit Sequence Alignment Editor Software 7.0.5.3 (Hall 1999) and Geneious Pro 4.5.4 (Drummond et al. 2009). Geneious and MAFFT (Katoh et al. 2009) were employed to align the sequences, using the default settings in both programs. The alignments were checked by eye using MacClade 4.08 (Maddison and Maddison 2005). Protein-coding sequences were translated into amino acids for alignment confirmation. Saturation was examined through the substitution saturation test (Xia et al. 2003) implemented in DAMBE 5.2.14 (Xia 2000). For the COI gene, the number of transitions $(s)$ and transversions $(v)$ was plotted against the evolution model distances with the same program. Saturation plots were examined separately for the first, second and third codon positions.

The most variable regions from the $16 \mathrm{~S}$ rRNA alignment were removed using both the default settings and the standard options for stringent and less stringent selection in Gblocks (Talavera and Castresana 2007). Excluding "indel-rich" regions, the tree was in general poorly resolved with lower node support. Therefore, final analyses were performed including all bases. Sequences of COI and $16 \mathrm{~S}$ were trimmed to 643 and 465 base pairs, respectively.

Individual gene analyses and a concatenated analysis were performed. To test for conflicting phylogenetic signal between genes, the incongruence length difference (ILD) test (Farris et al. 1995) was conducted as the partition homogeneity test in PAUP 4.0b10 (Swofford 2003). Test settings consisted of 10 random stepwise additions (100 replicates) with TBR branch swapping.

The software jModelTest 0.1 (Posada 2008) was employed to determine the best-fit nucleotide substitution model for each gene and accompanying evolutionary parameter values for the data. ProtTest 1.4 (Abascal et al. 2005) was employed to infer the best-fit model of protein evolution. Akaike information criterion (AIC) (Akaike 1974) was used in both programmes to find the best evolutionary model. The evolution model obtained for the $16 \mathrm{~S}$ rDNA was the Transitional model $+\mathrm{I}+\mathrm{G}$ (Rodriguez et al. 1990), with a gamma shape value of 0.3670 . The General Time Reversible $+\mathrm{I}+\mathrm{G}$ (Tavaré 1986) was the evolution model for COI gene and concatenated sequences, with gamma shape values of 0.3640 and 0.3970 , respectively. The model of amino acids substitution for COI protein was the model described by Henikoff and Henikoff (1992) based on Block substitution matrices, BLOSUM62+I+G+F.

Maximum likelihood (ML) analyses, for both individual and concatenated genes, were conducted using the 
software RAxML v. 7.0.4 (Stamatakis et al. 2008), and node support was assessed with nonparametric bootstrapping (BS) with 5,000 replicates, random starting trees and parameters estimated from each dataset under the model selected for the original dataset. Bayesian inference analyses (BI) were performed using the software MrBayes v3.1.2 (Ronquist and Huelsenbeck 2003). For these analyses, 6 substitution types (nst $=6$ ) were used according to the evolutionary model determined by jModeltest. Analyses were initiated with random starting trees and run for 5,000,000 generations and four chains. The Markov chains were sampled each 1,000 generations. Two independent runs were performed. The program TRACER v1.5 (Lemey et al. 2009) was employed for determining when the log likelihood (ln 1) of sampled trees reached a stationary distribution. Generations sampled before the chain reached stationary were discarded as burn-in. From the resulting trees, 500 were discarded (10\% of the generations) and the remaining trees of both runs were used to create $50 \%$ majority-rule consensus tree and to estimate Bayesian posterior probabilities. Only nodes supported by BS $\geq 75$ and $\mathrm{PP} \geq 0.90$ are discussed (Hillis and Bull 1993; Alfaro et al. 2003).

In order to compare the genetic distances among specimens of Polycerinae, we calculated the pairwise uncorrected $p$-distances for COI using PAUP* $4.0 \mathrm{~b}$ 10.0. All codon positions were considered for the analysis.

\section{Results}

The substitution saturation test for COI gene was not significant for Polycerinae, indicating that this gene was not saturated for substitutions within this subfamily. The saturation plots over divergence divided by codon for all dataset indicated that transversions were not saturated in the third position; therefore, nucleotides occupying this position were not excluded from the analyses. The genetic divergence (uncorrected $p$-distance) for COI within Polycerinae reached $19.5 \%$ between some species of different genera (e.g., Polycera sp. B (Hawaii) and Palio dubia) (Table 2).

The ILD test showed no significant conflicting signal between the two genes. Consequently, a combined dataset was used for phylogenetic reconstruction. The trees obtained from the concatenated genes were very similar to those retrieved from COI and 16S genes independently, with the same strongly supported branches, with $16 \mathrm{~S}$ being the least informative. On the other hand, the COI amino acid sequences were poorly informative (data not shown).

The combined dataset yielded a sequence alignment of 1,108 positions comprising 465 bp (16S) and 643 bp (COI, with 219 inferred amino acids).

The result of the maximum likelihood and Bayesian concatenated analyses is shown in Fig. 1, including the
Table 2 Minimum COI gene pairwise uncorrected p-distances amongst some Polycera species

\begin{tabular}{|c|c|}
\hline Species & $\begin{array}{l}\text { COI genetic } \\
\text { distances }(\%)\end{array}$ \\
\hline $\begin{array}{l}\text { P. quadrilineata MNCN15.05/55455 (Sweden) } \\
\text { versus } P \text {. quadrilineata MNCN15.05/55459 } \\
\text { (Sweden) }\end{array}$ & 0.0 \\
\hline $\begin{array}{l}\text { P. capensis CASIZ176375 (SAfrica) versus } \\
\text { P. capensis CASIZ176280 (SAfrica) }\end{array}$ & 0.15 \\
\hline $\begin{array}{l}\text { P. capensis CASIZ176907 (SAfrica) versus } \\
\text { P. capensis CASIZ176280 (SAfrica) }\end{array}$ & 0.64 \\
\hline $\begin{array}{l}\text { P. capensis CASIZ176907 (SAfrica) versus } \\
\text { P. capensis CASIZ176375 (SAfrica) }\end{array}$ & 0.79 \\
\hline $\begin{array}{l}P . \text { sp. A CASIZ176387 (SAfrica) versus } P . \mathrm{sp} \text {. } \\
\text { A CASIZ176169 (SAfrica) }\end{array}$ & 1.40 \\
\hline $\begin{array}{l}\text { P. faeroensis } \mathrm{MNCN} 15.05 / 55503.1 \text { (Portugal) versus } \\
\text { P. faeroensis } \mathrm{MNCN} 15.05 / 55503.2 \text { (Portugal) }\end{array}$ & 1.90 \\
\hline $\begin{array}{l}\text { P. cf. capensis MNCN15.05/55470 (Australia) versus } \\
\text { P. capensis CASIZ176280 (SAfrica) }\end{array}$ & 2.18 \\
\hline $\begin{array}{l}P \text {. sp. A CASIZ176169 (SAfrica) versus } P \text {. capensis } \\
\text { CASIZ176375 (SAfrica) }\end{array}$ & 9.64 \\
\hline $\begin{array}{l}P . \text { sp. A CASIZ176169 (SAfrica) versus } P \text {. cf. } \\
\text { capensis } \text { MNCN15.05/55470 (Australia) }\end{array}$ & 10.1 \\
\hline $\begin{array}{l}\text { P. quadrilineata } \mathrm{MNCN} 15.05 / 55465 \text { (Sweden) } \\
\text { versus } P \text {. faeroensis } \mathrm{MNCN} 15.05 / 55503.2 \\
\text { (Portugal) }\end{array}$ & 12.3 \\
\hline $\begin{array}{l}\text { P. tricolor CASIZ 76438a (California) versus } \\
\text { P. hedgpethi MNCN15.05/55493 (Morocco) }\end{array}$ & 12.8 \\
\hline $\begin{array}{l}P . \text { sp. B CASIZ176795 (Hawaii) versus } P \text {. capensis } \\
\text { CASIZ176375 (SAfrica) }\end{array}$ & 13.1 \\
\hline $\begin{array}{l}P \text {. sp. B CASIZ176795 (Hawaii) versus } P \text {. cf. } \\
\text { capensis MNCN15.05/55470 (Australia) }\end{array}$ & 14.0 \\
\hline $\begin{array}{l}\text { P. hedgpethi MNCN15.05/55493 (Morocco) versus } \\
\text { Palio dubia MNCN15.05/55467 (Sweden) }\end{array}$ & 14.0 \\
\hline $\begin{array}{l}P \text {. sp. C CASIZ120773 (Marshall Island) versus } \\
\text { P. cf. capensis MNCN15.05/55470 (Australia) }\end{array}$ & 14.9 \\
\hline $\begin{array}{l}\text { P. sp. C CASIZ120773 (Marshall Island) versus } \\
\text { P. capensis CASIZ176280 (SAfrica) }\end{array}$ & 15.1 \\
\hline $\begin{array}{l}P . \text { sp. B CASIZ176795 (Hawaii) versus } P . \text { sp. } \\
\text { C CASIZ120773 (Marshall Island) }\end{array}$ & 16.6 \\
\hline $\begin{array}{l}P . \text { sp. C CASIZ120773 (Marshall Island) versus } \\
P . \text { sp. A CASIZ176169 (SAfrica) }\end{array}$ & 17.3 \\
\hline $\begin{array}{l}\text { P. sp. C CASIZ120773 (Marshall Island) versus } \\
\text { P. faeroensis MNCN15.05/55503.1 (Portugal) }\end{array}$ & 18.2 \\
\hline $\begin{array}{l}\text { P. sp. B CASIZ176795 (Hawaii) versus Palio dubia } \\
\text { GB }\end{array}$ & 19.5 \\
\hline
\end{tabular}

respective bootstraps supports values (BS) and posterior probabilities (PP). The monophyly of Polycerinae was strongly supported by both the maximum likelihood and the Bayesian analyses ( $\mathrm{BS}=100, \mathrm{PP}=1)$ with the genus Crimora as the sister taxon $(\mathrm{BS}=85, \mathrm{PP}=1)$. Within Polycerinae, the relationships between genera were not resolved, originating a polytomy that included all the studied genera (Thecacera, Polycerella, Palio, and Polycera). Moreover, specimens of the genus Gymnodoris ( $G$. 


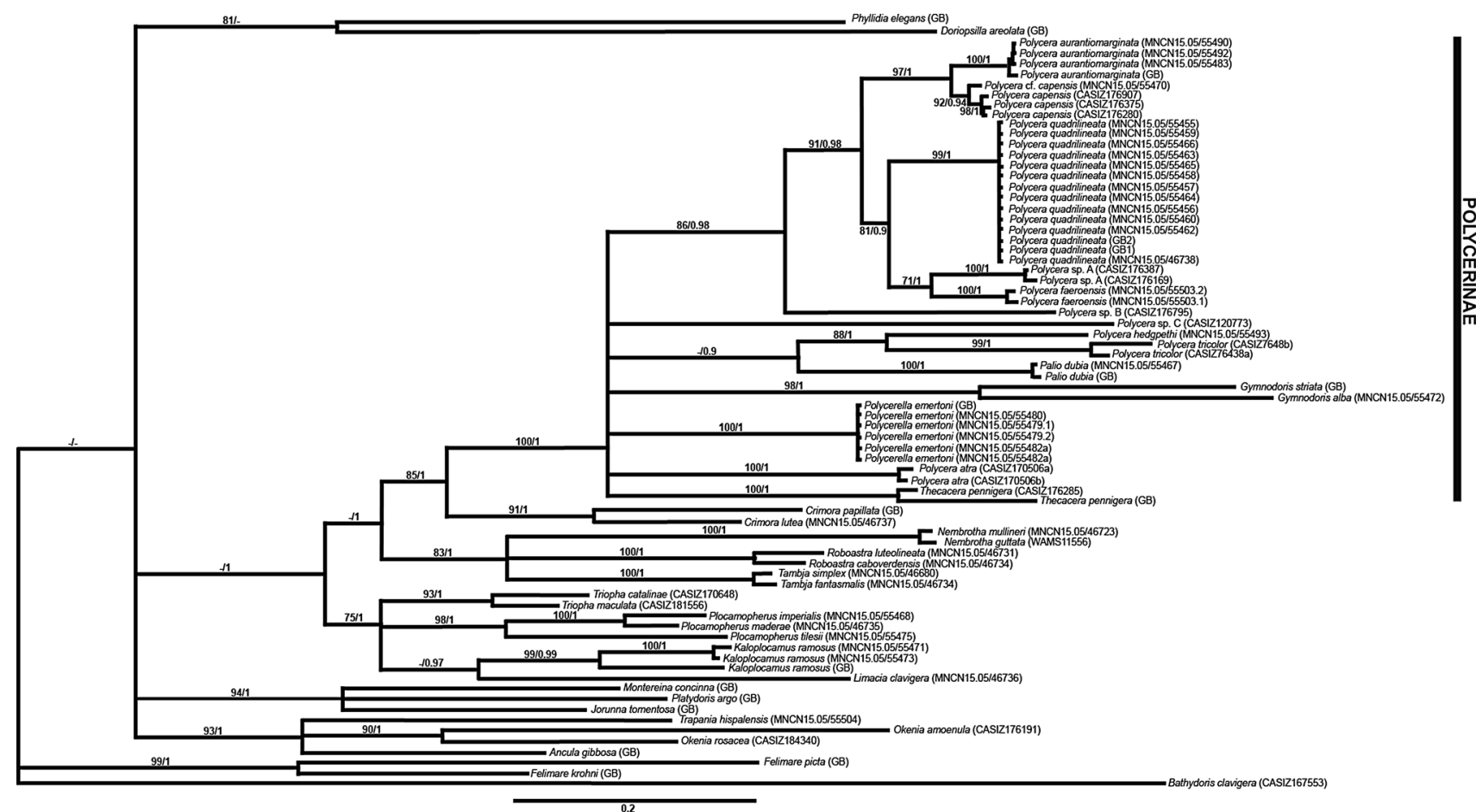

Fig. 1 Phylogenetic hypothesis based on combined molecular data (COI and 16S) represented by Bayesian inference. Numbers below the branches represent bootstraps supports values from the Maximum

alba and G. striata) clustered within Polycerinae $(\mathrm{BS}=100, \mathrm{PP}=1)$.

The relationships within Polycera remained unresolved (Fig. 1). Polycera tricolor appeared sister to Polycera hedgpethi $\quad(\mathrm{BS}=88, \quad \mathrm{PP}=1$, minimum uncorrected $p$-distance $=12.8 \%)$ and both bounded together with Palio dubia, but this relationship is not supported. Polycera atra formed an independent clade as well as the specimen Polycera sp. CASIZ 120773 from the Marshall Islands. The remaining Polycera were included in a strongly supported clade ( $\mathrm{BS}=86, \mathrm{PP}=0.98$ ), with the specimen Polycera sp. CASIZ 176795 from Hawaii as sister to the rest of the taxa. This clade was divided into two well-supported subclades: one contained P. sp. from South Africa, as well as $P$. quadrilineata and $P$. faeroensis $(\mathrm{BS}=81, \mathrm{PP}=0.9$ ). All specimens of $P$. quadrilineata were grouped together regardless of their geographical origin with high posterior probability (1) and bootstrap value (99). The other subclade contained Polycera aurantiomarginata, $P$. cf. capensis from Australia, and three other specimens of $P$. capensis from South Africa ( $\mathrm{BS}=97, \mathrm{PP}=1$ ). The COI genetic diverges between some of the studied specimens are summarized in Table 2.

The species considered from other subfamilies were grouped by genus, but the relationships between the subfamilies were not fully resolved.
Likelihood analyses and posterior probabilities from Bayesian Inference, respectively (BS/PP). The dashes indicate bootstrap values below 75 and posterior probabilities below 0.9

\section{Discussion}

The monophyly of the subfamily Polycerinae is supported by the molecular data, confirming its phylogenetic identity as revealed by morphological studies (Alder and Hancock 1845; Odhner 1941). Unfortunately, the relationships within Polycerinae as well as between the studied species of Polycera remain unresolved. This result is probably explained by the fact that this study includes only a small representation of polycerid diversity. Including more species and nuclear markers may help to resolve this issue.

A controversial subject in current literature is the systematic position of Gymnodoris. Our data strongly support that Gymnodoris specimens analyzed (G. alba and G. striata) cluster within the subfamily Polycerinae with high bootstrap support and posterior probability values (Fig. 1). At present, these species are classified within an independent family, Gymnodorididae (Odhner 1941; Bouchet and Rocroi 2005), due to some differential traits like a different buccal apparatus and the capacity to feed on other nudibranchs (Macnae 1958; McDonald and Nybakken 1996). However, traditional classifications included gymnodorids as subfamily Gymnodoridinae within the family Polyceridae (Eliot 1903). Macnae (1958) considered that the differences between gymnodorids and polycerids were minor and the resemblances were too important to permit the separation in two families. Our results strongly support the 
Fig. 2 Zoom of a branch of the bayesian inference tree of the concatenated dataset. Numbers below the branches represent bootstraps supports values (BS) from the maximum likelihood analyses and numbers under the branches represent posterior probabilities (PP). Photographs on the right represent a $P$. cf. capensis MNCN 15.05/55470, photo by Dave Harasti; b $P$. capensis CASIZ 176375, photo by T.M. Gosliner; c $P$. capensis CASIZ 176280, photo by T.M. Gosliner; d $P$. sp. A CASIZ 176387, photo by T.M. Gosliner; e $P$. sp. A CASIZ 176169, photo by T.M. Gosliner

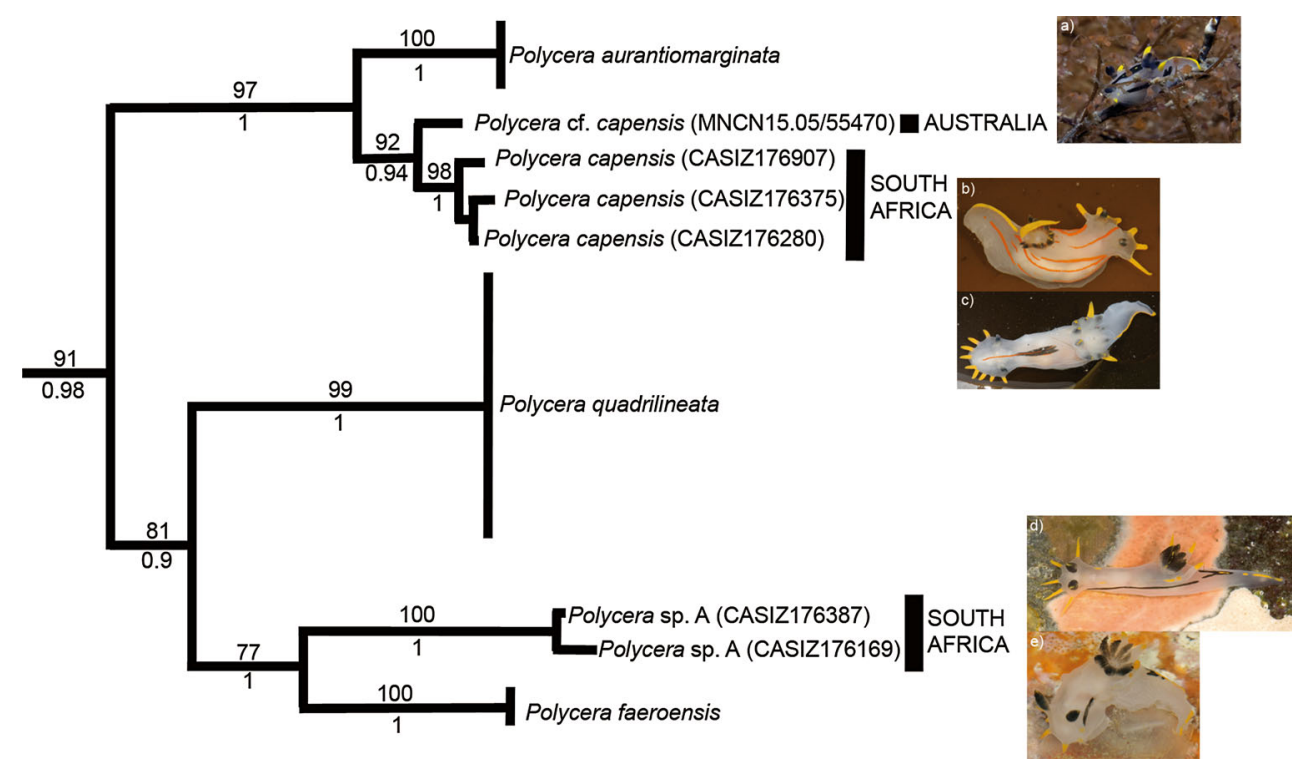

old classification over the current one. However, although we strongly believe in our results, to date, Gymnodorididae comprises four genera and at least 19 species. We therefore think that more specimens are needed together with additional nuclear genes as well as further phylogenetic analysis to clarify the phylogenetic position of gymnodorids.

Within Polycera only P. aurantiomarginata, P. capensis, $P$. quadrilineata, $P$. faeroensis, two specimens of $P$. sp. A from South Africa (CASIZ176169 and CASIZ176387) and one specimen of an unidentified species (Polycera sp. B) formed a strongly supported clade. P. faeroensis appeared closely related to the South African Polycera sp. A and this clade is sister to P. quadrilineata (Fig. 2). $P$. faeroensis is morphologically similar to $P$. quadrilineata with some differences in cephalic processes (8 or more vs. 4-6, respectively). A close relationship between $P$. quadrilineata and $P$. faeroensis was mentioned by Odhner (1941), who postulated the separation between these species according to wing-like expansions in the jaws, while Lemche (1929) suggested that $P$. faeroensis was intermediate between the genera Polycera and Palio. Our results showed high genetic divergence between these two species (minimum uncorrected $p$-distance $=12.3 \%$ ), solving the controversy and corroborating the convenience of genetic analysis to improve taxonomic information obtained from morphological studies. On the other hand, the position of $P$. aurantiomarginata and $P$. quadrilineata in our study could fit with the morphological comparison of both species described by García and Bobo (1984). Their external morphology, radula and jaws are very similar; however, they differ in coloration of some specific parts, number of cephalic processes and lamellas of the rhinophores as well as some aspects of the larval development and spawning (García and Bobo 1984; Martínez-Pita et al. 2006).
In general, Polycera specimens were grouped by species with high bootstrap support and posterior probability values, regardless of the geographical origin of the sample (Fig. 1). An unexpected result was that some specimens from South Africa labeled in the field as Polycera capensis (CASIZ 176169 and CASIZ 176387) did not cluster together with the remaining $P$. capensis included on this study (three specimens from South Africa and one specimen from Australia) (Fig. 2). In fact, the minimum uncorrected $p$-distance for COI between specimens of these two different clades $(10 \%)$ clearly showed that they belong to different species (Table 2). In view of this result, we tried to re-examine the type material of Polycera capensis, but unfortunately "Le dessin original ná pas été conserve, non plus que l'échantillon" (Pruvot-Fol 1934). However, based on Quoy and Gaimards' original description of Polycera capensis and comparison with Quoy and Gaimard's plate of the type specimen, it seems more likely that the specimens here identified as a $P$. capensis-like animal from Australia are the true $P$. capensis. Allan (1932) described the Australian species known as Polycera capensis as a new and different species, Polycera conspicua. Later on, Pruvot-Fol (1934) re-named Allan's specimens as Polycera capensis; hence, Polycera conspicua became its synonym (Thompson 1975). Odhner (1941) supported this synonymy, but wrote about the differences between the different authors' pictures that he considered to be due to the morphological intraspecific variation. He thought that Polycera capensis had an Indian origin and later spread to the South. In 1958, Macnae also described variations in color and size of the mantle processes in spite of his agreement with the synonymy. In 1975, Thompson doubted that Pruvot-Fol (1934) and Odhner (1941) were correct in referring to Allan's specimens as Polycera capensis. Based on their 
color form, the specimens described and figured by Allan (1932) from Sydney (Australia) as P. conspicua are also very similar to the specimen from Australia. We also dissected these specimens and compared them to the specimens studied by Macnae (1958), but since there are no pictures of Macnae's animals, we cannot be sure to which species the radula and the reproductive system showed in that paper belong.

Thus, one of the key findings of this study is that there are clearly at least two sympatric species of Polycera in South Africa, one more closely related to P. faeroensis and the other one more closely related to the Polycera capensis-like animal from Australia. It has been hypothesized that Polycera capensis was introduced from South Africa to Australia by fouling, and it has spread $200 \mathrm{~km}$ since then (Macnae 1958; Rudman 1998; Willan 2000). The maximum uncorrected $p$-distance for COI between the specimen of Polycera capensis from Australia and those from South Africa was $2.9 \%$ (Table 2). Hebert et al. (2003) suggested a mean molluscan divergence of $11.1 \pm 5.1 \%$ for COI between sister species. Carmona et al. (2011) used maximum value of divergence for $\mathrm{COI}$ for the same species of $7.3 \%$, which is the value that they found between specimens of the same species from the Mediterranean Sea and the Western Atlantic. Wilson et al. (2009) even reduced this threshold to $5 \%$ for well-supported sister pairs. Due to the fact that different groups of organisms, even within the same genus or family, can have different rates of molecular evolution (Hebert et al. 2003; Williams et al. 2003), and the use of general genetic thresholds to distinguish between species is difficult to apply. Therefore, we calculated a threshold based on our data. Within Polycerinae, individuals of the same species had a genetic divergence from 0 to $4 \%$ for the COI gene. If this value were taken as threshold, specimens of $P$. capensis from Australia and from South Africa would be the same species as confirmed by our morphological studies.

Although our results suggest that the Australian specimen is conspecific with the South African ones, it is clear that Polycera capensis needs a deep morphological and molecular revision with larger sample sizes from Australia and South Africa to clarify this matter. Above all, a complete morphological redescription of Polycera capensis based on the study of material from the type locality is needed in order to objectively define this species and designate a neotype.

Acknowledgments We are grateful to Ivan G. Pola who helped with laboratory tasks. We also thank Rafael Araujo and Francisco Javier de Andrés Cobeta (Museo Nacional de Ciencias Naturales, Madrid), Elizabeth Kools (California Academy of Sciences, San Francisco) and the Museu Municipal de Funchal (Madeira) for the loan of the specimens. We are indebted to Lucas Cervera for providing the specimens from Morocco and Cádiz and for helping us with bibliography and comments. We are also grateful to those who read and commented on the manuscript. Special thanks to Valda Fraser. Dave Harasti kindly collected and photographed the Australian specimens. M. Pola is indebted to P. Sundberg and the Swedish Taxonomy Initiative for the invitation to the Lovén Centre for Marine Science (Tjärno, Sweden) where many of the specimens were collected. This study was partially supported by the Erasmus Mundus Master in Marine Biodiversity Conservation and the Regional Ministry of Education and Science of Principado de Asturias and by the Grant SV-PA-13-ECOEMP-41 of the Principado de Asturias.

\section{References}

Abascal F, Zardoya R, Posada D (2005) ProtTest: selection of best-fit models of protein evolution. Bioinformatics 21:2104-2105

Akaike H (1974) A new look at the statistical model identification. IEEE Trans Autom Control 19:716-722

Alder J (1841) Observations on the genus Polycera of Cuvier, with descriptions of two new British species. Ann Mag Nat Hist 6:337-342

Alder J, Hancock A (1845-1855) A monograph of the British nudibranchiate Mollusca. Parts 1-7. Ray Society, London

Alfaro ME, Zoller S, Lutzoni F (2003) Bayes or bootstrap? A simulation study comparing the performance of Bayesian Markov chain Monte Carlo sampling and bootstrapping in assessing phylogenetic confidence. Mol Biol Evol 20:255-266

Allan J (1932) Australian nudibranchs. Aust Zool 7:87-105

Bergh LSR (1877) Malacologische Untersuchungen. In: Semper C (ed) Reisen im Archipel der Philippinen. Zweiter Theil, Wissenschaftliche Resultate 2(11):429-494

Bergh LSR (1890) Die Cladohepatischen Nudibranchiern. Zool Jahrb Abt Syst Geogr Biol Tiere Jena 5:1-75

Bergh LSR (1902) The Danish Expedition to Siam 1899-1900. 1. Gasteropoda Opisthobranchiata. Det Kongelige Danske Videnskabernes Selskabs Skrifter 6. Raekke, Naturvidenskabelig og Mathematisk Afdeling 12(2):153-218

Bergh LSR (1906) Über clado- und holohepatische nudibranchiate Gastropoden. Zool Jahrb Abt Syst Geogr Biol Tiere 23:737-742

Bouchet P (2013) Gymnodorididae. Accessed through: World Register of Marine Species at http://www.marinespecies.org/aphia. php?p=taxdetails\&id=23049 on 2013-10-09

Bouchet P, Rocroi JP (2005) Classification and nomenclator of gastropod families. Malacologia 47(1-2):1-397

Boxshall G, Mees J, Costello MJ, Hernandez F, Vandepitte L, Gofas S, Hoeksema BW, Klautau M, Kroh A, Poore GCB, Read G, Stöhr S, de Voogd NJ, Walter CT, De Broyer C, Horton T, Kennedy M (eds) (2013) World Register of Marine Species. Accessed at http://www.marinespecies.org on 2013-10-07

Burn R (1967) Notes on an overlooked nudibranch genus, Roboastra Bergh, 1877, and two allied genera (Mollusca: Gastropoda). Aust Zool 14:212-222

Carmona L, Malaquias MAE, Gosliner TM, Pola M, Cervera JL (2011) Amphi-Atlantic distributions and cryptic species in sacoglossan sea slugs. J Mollusc Stud 77:401-412

Carmona L, Pola M, Gosliner TM, Cervera JL (2013) A tale that morphology fails to tell: a molecular phylogeny of Aeolidiidae (Aeolidida, Nudibranchia, Gastropoda). PLoS ONE 8(5):e63000. doi:10.1371/journal.pone. 0063000

Dayrat B (2005) Towards integrative taxonomy. Biol J Linn Soc 85(3):407-415

Drummond AJ, Ashton B, Cheung M, Heled J, Kearse M, Moir R, Stones-Havas S, Thierer T, Wilson A (2009) Geneious v4.6. Available from: http://www.geneious.com 
Eliot C (1903) Nudibranchiata, with some remarks on the families and genera and description of a new genus, Doridomorpha. In: Gardiner JS (ed) The fauna and geography of the Maldive and Laccadive Archipelagoes 2. University Press, Cambridge, pp 540-573

Estoup A, Largiader CR, Perrot E, Chourrout D (1996) Rapid onetube DNA extraction for reliable PCR detection of fish polymorphic markers and transgenes. Mol Mar Biol Biotech $5: 295-298$

Fahey SJ (2003) Phylogeny of Halgerda (Mollusca: Gastropoda) based on combined analysis of mitochondrial COI and morphology. Invertebr Syst 17:617-624

Fahey SJ, Gosliner TM (2001) The phylogeny of Halgerda (Opisthobranchia: Nudibranchia) with the description of a new species from Okinawa. Zool Scr 30:199-213

Fahey SJ, Gosliner TM (2004) A phylogenetic analysis of the Aegiridae Fischer, 1883 (Mollusca, Nudibranchia, Phanerobranchia) with descriptions of eight new species and a reassessment of phanerobranch relationships. Proc Calif Acad Sci 55(34): 613-689

Fall A, Thompson RCA, Hobbs RP, Morgan-Ryan U (2003) Morphology is not reliable tool for delineating species within Cryptosporidium. J Parasitol 89:399-402

Farris JD, Källersjö M, Kluge AG, Bult C (1995) Constructing a significance test for incongruence. Syst Biol 44:570-572

Folmer O, Black M, Hoeh W, Lutz R, Vrijenhoek R (1994) DNA primers for amplification of mitochondrial cytochrome $c$ oxidase subunit I from diverse metazoan invertebrates. Mol Mar Biol Biotech 3:294-299

García JC, Bobo A (1984) Una nueva especie de Polycera Cuvier (Mollusca: Nudibranchia) del litoral ibérico. Cah Biol Mar 25:361-373

Gosliner TM (2004) Phylogenetic systematics of Okenia, Sakishimaia, Hopkinsiella and Hopkinsia (Nudibranchia: Goniodorididae) with descriptions of new species from the tropical IndoPacific. Proc Calif Acad Sci 55(5):125-161

Hall TA (1999) BioEdit: a user-friendly biological sequence alignment editor and analysis program for Windows 95/98/NT. Nucleic Acids Symp Ser 41:95-98

Hebert PDN, Ratnasingham S, de Waard JR (2003) Barcoding animal life: cytochrome $c$ oxidase subunit 1 divergences among closely related species. Proc R Soc Lond B Biol 270:S96-S99

Henikoff S, Henikoff J (1992) Amino acid substitution matrices from protein blocks. PNAS 89:10915-10919

Hillis DM, Bull JJ (1993) An empirical test of bootstrapping as a method for assessing confidence in phylogenetic analysis. Syst Biol 42:182-192

Johnson RF (2010) Breaking family ties: taxon sampling and molecular phylogeny of chromodorid nudibranchs (Mollusca, Gastropoda). Zool Scr 40(2):137-157

Johnson RF, Gosliner TM (2012) Traditional taxonomic groupings mask evolutionary history: a molecular phylogeny and new classification of the chromodorid nudibranchs. PLoS ONE 7:1-15

Katoh K, Asimenos G, Toh H (2009) Multiple alignment of DNA sequences with MAFFT. In: Posada D (ed) Bioinformatics for DNA sequence analysis. Methods Mol Biol vol 537, pp 39-64

Lemche H (1929) Gastropoda Opisthobranchiata. Zool Faroes 52:1-35

Lemey P, Rambaut A, Drummond AJ, Suchard MA (2009) Bayesian phylogeography finds its roots. PLoS Comput Biol 5(9):e1000520

MacFarland FM (1905) Preliminary account of Dorididae of Monterey Bay, California. Proc Biol Soc Wash 18:35-54

Macnae W (1958) The families Polyceridae and Goniodorididae (Mollusca, Nudibranchiata) in southern Africa. Trans R Soc S Afr 35(4):341-372
Maddison DR, Maddison WP (2005) MacClade 4, v. 4.08 for OSX. Sinaur Associates, Sunderland, MA

Marcus ER (1964) A new species of Polycera (Nudibranchia) from California. Nautilus 77(4):128-131

Martínez-Pita I, Sánchez-España AI, García FJ (2006) Some aspects of the reproductive biology of two Atlantic species of Polycera (Mollusca: Opisthobranchia). J Mar Biol Assoc UK 86:391-399

McDonald GR, Nybakken JW (1996) A list of the worldwide food habits of nudibranchs. http://www.theveliger.org/nudibranch food.htlm

Medina M, Collins AG (2003) The role of molecules in understanding molluscan evolution. In: Lydeard C, Lindberg DR (eds) Molecular systematics and phylogeography of molluscs. Smithsonian Books, Washington, pp 14-44

Medina M, Walsh P (2000) Molecular systematics of the Order Anaspidea based on mitochondrial DNA sequences (12S, 16S, and COI). Mol Phylogenet Evol 15(1):41-48

Medina M, Camacho-García Y, Vallés Y, Valdés A, Gosliner TM (2001) Gymnodorid nudibranchs from the eastern Pacific: a preliminary taxonomic revision of the genera Tambja, Roboastra and Nembrotha. Abstracts Western Society of Malacologists Annual Meeting, San Diego

Mikkelsen PM (1998) Review of shell reduction and loss in traditional and phylogenetic molluscan systematics, with experimental manipulation of a negative gain character. Am Malacol Bull 14(2):201-218

Millen S, Martinov A (2005) Redescription of the nudibranch genera Akiodoris Bergh, 1879 and Armodoris Minichev, 1972 (Suborder Doridacea), with a new species of Akidoris and a new family Akiodorididae. Proc Calif Acad Sci Ser 4 56(1):1-22

Müller OF (1776) Zoologiae danicae. Prodromus, seu animalium Daniae et Norvegiae indigenarum characters, nomina, et synonyma imprimis popularium, pp I-XXXII, 1-282

Odhner NH (1934) The Nudibranchiata. British Museum (Terra Nova) Expedition, 1910. Nat Hist Rep 7(5):229-310

Odhner NH (1941) New polycerid nudibranchiate mollusca and remarks on this family. Meddelanden från Göteborgs Musei Zoologiska Ardelning 91:1-20

Ornelas-Gatdula E, Camacho-García Y, Schrödl M, Padula V, Hooker Y, Gosliner TM, Valdés Á (2012) Molecular systematics of the 'Navanax aenigmaticus' species complex (Mollusca, Cephalaspidea): coming full circle. Zool Scr 41:374-385

Ortea J, Espinosa J, Caballer M (2004) Nuevos taxones y registros de la familia Polyceridae (Mollusca: Nudibranchia) en las costas de Cuba. Avicennia 17:101-106

Palumbi SR, Martin AP, Romano S, McMillan WO, Stice L, Grabowski G (1991) The simple fool's guide to PCR. Special Publ. Department of Zoology, University of Hawaii, Honolulu

Pola M, Gosliner TM (2010) The first molecular phylogeny of cladobranchian opisthobranchs (Mollusca, Gastropoda, Nudibranchia). Mol Phylogen Evol 56:931-941

Pola M, Cervera JL, Gosliner TM (2003) The genus Roboastra Bergh, 1877 (Nudibranchia, Polyceridae, Nembrothinae) in the Atlantic Ocean. Proc Calif Acad Sci 54(22):381-392

Pola M, Cervera JL, Gosliner TM (2005a) Review of the systematics of the genus Roboastra Bergh, 1877 (Nudibranchia, Polyceridae, Nembrothinae) with the description of a new species from Galápagos Islands. Zool J Linn Soc 144:167-189

Pola M, Cervera JL, Gosliner TM (2005b) Four new species of Tambja Burn, 1962 (Mollusca, Nudibranchia, Polyceridae) from the Indo-Pacific. J Mollusc Stud 7(3):257-267

Pola M, Cervera JL, Gosliner TM (2005c) A new species of Tambja Burn, 1962 (Nudibranchia, Polyceridae, Nembrothinae) from southern Brazil. J Mar Biol Assoc UK 85:979-984 
Pola M, Cervera JL, Gosliner TM (2006a) Description of two new phanerobranch nembrothid species (Nudibranchia: Polyceridae: Doridacea). J Mar Biol Assoc UK 86(2):403-409

Pola M, Cervera JL, Gosliner TM (2006b) Taxonomic revision and phylogenetic analysis of the genus Tambja Burn, 1962 (Mollusca, Nudibranchia, Polyceridae). Zool Scr 35(5):491-530

Pola M, Vallès Y, Cervera JL, Medina M, Gosliner TM (2006c) Taxonomic status of Tambja abdere and Tambja fusca based on morphological and molecular evidence, with comments on the phylogeny of the subfamily Nembrothinae (Nudibranchia, Polyceridae). Ann Zool Fennici 43(1):52-64

Pola M, Cervera JL, Gosliner TM (2007) Phylogenetic relationships of Nembrothinae (Mollusca: Doridacea: Polyceridae) inferred from morphology and mitochondrial DNA. Mol Phylogenet Evol 43:726-742

Pola M, Cervera JL, Gosliner TM (2008a) Revision of the Indo-Pacific genus Nembrotha (Nudibranchia: Dorididae: Polyceridae), with a description of two new species. Sci Mar 72(1):145-183

Pola M, Cervera JL, Gosliner TM (2008b) Description of the first Roboastra species (Nudibranchia, Polyceridae, Nembrothinae) from the western Atlantic. B Mar Sci 83(2):391-399

Pola M, Camacho-García YE, Gosliner TM (2012) Molecular data illuminate cryptic nudibranch species: the evolution of the Scyllaeidae (Nudibranchia: Dendronotina) with a revision of Notobryon. Zool J Linn Soc 165:311-336

Posada D (2008) JModelTest: phylogenetic model averaging. Mol Biol Evol 25:1253-1256

Pruvot-Fol A (1934) Les opisthobranches de Quoy et Gaimard. Arch Mus Natl Hist Nat (Paris) 11(6):13-92

Quoy JRC, Gaimard JP (1824) Description des Mollusques, Chapter 11. In: Freycinet, Louis de. 'Voyage autor du monde executé sur les corvettes de S.M. l'Uranie et la Physicienne pendant les années 1817-1820'. Zoology, pt. 2, Paris, pp 410-516, pls 66-72, 75, 87

Robilliard GA (1971) A new species of Polycera (Opisthobranch: Mollusca) from the northeastern Pacific, with notes on other species. Syesis 4:235-243

Rodriguez F, Oliver JF, Marin A, Medina JR (1990) The general stochastic model of nucleotide substitution. J Theor Biol 142:485-501

Ronquist F, Huelsenbeck JP (2003) MRBAYES 3, Bayesian phylogenetic inference under mixed models. Bioinformatics 19:15721574

Rudman WB (1998) Suborder Doridina. In: Beesley PL, Ross GJB, Wells A (eds) Mollusca: the Southern synthesis. Fauna of Australia, vol 5 B, CSIRO Publishing, Melbourne, pp 990-1001

Schrödl M, Wägele H, Willan R (2001) Taxonomic redescription of the Doridoxidae (Gastropoda: Opistobranchia), an enigmatic family of deep-water nudibranchs, with discussion of basal nudibranch phylogeny. Zool Anz 240:83-97

Stamatakis A, Hoover P, Rougemont J (2008) A fast bootstrapping algorithm for the RAxML web-servers. Syst Biol 57(5):758-771

Swofford DL (2003) PAUP*. Phylogenetic Analysis Using Parsimony (*and other methods). Version 4. Sinauer Associates, Sunderland, MA

Talavera G, Castresana J (2007) Improvement of phylogenies after removing divergent and ambiguously aligned blocks from protein sequence alignments. Syst Biol 56:564-577

Tavaré S (1986) Some probabilistic and statistical problems in the analysis of DNA sequences. In: Miura RM (ed) Some mathematical questions in biology-DNA sequence analysis. American Mathematical Society, Providence, RI, pp 57-86

Thöllesson M (1999a) Phylogenetic analysis of Euthyneura (Gastropoda) by means of the 16SrRNA gene: use of a "fast" gene for "higher-level" phylogenies. Proc R Soc Lond B 266:75-83

Thöllesson M (1999b) Phylogenetic analysis of dorid nudibranchs (Gastropoda: Doridacea) using the mitochondrial 16S rRNA gene. J Mollusc Stud 65:335-353
Thöllesson M (2000) Increasing fidelity in parsimony analysis of dorid nudibranch by differential weighting, or a tale of two genes. Mol Phylogenet Evol 16:161-172

Thompson TE (1975) Dorid nudibranchs from eastern Australia (Gastropods, Opisthobranchia). J Zool Lond 176:477-517

Turner LM, Wilson NG (2008) Polyphyly across oceans: a molecular phylogeny of the Chromodorididae (Mollusca: Nudibranchia). Zool Scr 37:23-42

Valdés A (2001) Depth related adaptations, speciation processes and evolution of color in the genus Phyllidiopsis (Mollusca: Nudibranchia). Mar Biol 139:485-496

Valdés A (2002) A phylogenetic analysis and systematics revision of the cryptobranch dorids (Mollusca, Nudibranchia, Anthobranchia). Zool J Linn Soc 136:535-636

Valdés A (2003) Preliminary molecular phylogeny of the radula-less dorids (Gastropoda: Opisthobranchia), based on 16S mtDNA sequence data. J Mollusc Stud 69:75-80

Valdés A, Gosliner TM (1999) Phylogeny of the radula-less dorids (Mollusca, Nudibranchia), with the description of a new genus and a new family. Zool Scr 28(3-4):315-360

Vallés Y, Gosliner TM (2006) Shedding light onto the genera (Mollusca: Nudibranchia) Kaloplocamus and Plocamopherus with description of new species belonging to these unique bioluminescent dorids. Veliger 48(3): 178-205

Wägele H (1989) Die gattung Bathydoris Bergh, 1884 (Gnathodoridacea) im phylogenetischen System der Nudibranchia (Opisthobranchia, Gastropoda). J Zool Syst Evol Res 27:273-281

Wägele JW (2005) Foundations of phylogenetic systematics. Verlag Dr. Friedrich Pfeil, München

Wägele H, Willan RC (2000) Phylogeny of the Nudibranchia. Zool J Linn Soc 130:83-181

Wägele H, Vonnemann V, Wägele W (2003) Towards a phylogeny of the opisthobranchia. In: Lydeard C, Lindberg DR (eds) Molecular systematics and phylogeography of mollusks. Smithsonian Books, Washington, pp 185-228

Wiens JJ, Penkrot TA (2002) Delimiting species using DNA and morphological variation and discordant species limits in Spiny Lizzards (Sceloporus). Syst Biol 51(1):69-91

Willan RC (2000) Family names, particularly Polyceridae and Aegiridae. Nudibranch News 3(3):1-3

Williams ST, Reid DG, Littlewood DTJ (2003) A molecular phylogeny of the Littorininae (Gastropoda: Littorinidae): unequal evolutionary rates, morphological parallelism and biogeography of the Southern Ocean. Mol Phylogenet Evol 28:60-86

Wilson NG, Lee MSY (2005) Molecular phylogeny of Chromodoris (Mollusca, Nudibranchia) and the identification of a planar spawning clade. Mol Phylogenet Evol 36(3):722-727

Wilson NG, Schrödl M, Halanych KM (2009) Ocean barriers and glaciation: evidence for explosive radiation of mitochondrial lineages in the Antarctic sea slug Doris kerguelensis (Mollusca, Nudibranchia). Mol Ecol 18:965-984

Wollscheid E, Wägele H (1999) First results on the phylogeny of the Nudibranchia (Gastropoda, Opisthobranchia) on 18SrDNA data and comparisons with morphological data. Mol Phylogenet Evol $13: 215-226$

Wollscheid-Lengeling E, Boore J, Brown W, Wägele H (2001) The phylogeny of Nudibranchia (Opisthobranchia, Gastropoda, Mollusca) reconstructed by three molecular markers. Org Divers Evol 1:241-256

Xia X (2000) Data analysis in molecular biology and evolution. Kluwer Academic Publishers, Boston

Xia XH, Xie Z, Salemi M, Chen L, Wang Y (2003) An index of substitution saturation and its application. Mol Phylogenet Evol $26: 1-7$ 